\title{
Family and Intimate Relationships
}

\author{
Dirk Konietzka, Michael Feldhaus, Michaela Kreyenfeld, \\ and Heike Trappe
}

\begin{abstract}
This article provides an overview on research on intimate relationships and the family in Germany since the turn of the millennium. It is argued that "German family sociology" has undergone major changes in various ways. In theoretical terms, micro-theoretical approaches have largely replaced former macro-sociological debates on de-institutionalization and pluralization of the family. In empirical research, the application of a life course perspective and the use of longitudinal data have become more and more established. In substantial terms, researchers have pursued integrative research perspectives that link family dynamics to other life domains. Not least, publication strategies shifted in favor of English language and international journals. In sum, these developments have fundamentally changed the German research landscape on intimate relationships and the family.
\end{abstract}

Keywords: Family forms, gender inequality, intergenerational relationships, life course, panel data

\section{Introduction}

Twenty years ago, Rudolf Richter published an overview article in the Soziologische Revue that summarized key topics of and developments in German family sociology. This piece is still enlightening to read today as it also elucidates the changes that family sociology in Germany has undergone in recent decades. From today's perspective, it seems striking that Richter's review was exclusively based on Germanlanguage monographs and edited volumes (which included a German translation of La Trame conjugale by Jean-Claude Kaufmann). One of the review's key topics was the discussion on de-standardization, de-institutionalization, pluralization, and the decay of the family (Richter, 2000: 62). The "pluralization thesis" (Pluralisierungsthese) echoed Ulrich Beck's individualization thesis, which had strongly influenced not just family sociology but sociology more broadly. Even though international researchers were also generating rich empirical evidence on the diversity of family forms and living arrangements around that time, the concept of "pluralization" never really gained currency beyond German-language sociology. The terms "diversity" and "destandardization" featured more prominently in the international debate, and scholars often reverted to concepts such as the "second demographic transition" to underpin empirical investigations of family change.

The pluralization thesis is a macro-sociological approach that still occasionally appears in contemporary German family sociology. However, many of the studies conducted since the turn of the century have been based on a micro foundation or 
have linked micro and macro perspectives in a multilevel approach. While Richter had noted as early as 2000 that rational-choice approaches were on the rise, he did not foresee how rapidly the focal point of attention would change in the years to come. While a range of theoretical and methodological approaches is still being used, it is clear that the attention of scholars has shifted to the individual actor.

In this context, the economic framework has provided a handy micro foundation for understanding decision-making within the family, such as how couples bargain about housework or allocate time between different activities. However, family sociologists who investigate family decision-making usually go beyond the narrow economic understanding of the rational-choice approach by integrating the cultural context or by reverting to concepts of bounded rationality. Furthermore, family sociologists have questioned the inclusion of the "given preferences" concept in the economic model. For example, the cross-cultural studies by Nauck (2007) used the value-of-children approach to show that individuals may satisfy different sets of preferences by having children. Family sociologists have also opened up the "black box" of decision-making by investigating the pathways that lead from intention to family behavior, often by borrowing from socio-psychological concepts, such as the theory of planned behavior (Ajzen, 1985). As longitudinal survey data on values, attitudes, and intentions have increasingly become available, researchers have been able to explore how values and attitudes influence subsequent family behavior and how cultural determinants are moderated or mediated by economic factors.

Another cornerstone of contemporary family sociology is the life course perspective (Huinink/Hollstein, LIFE COURSE, this volume). The life course serves as a useful framework for empirical investigations that focus on the timing and sequencing of family behavior. Marriage, divorce, first birth, subsequent birth(s), partnership formation, separation, re-partnering, and leaving the parental home are among the processes that have been scrutinized in empirical life course research. The life course concept also represents a powerful approach for investigating how individual family behavior leads to family change at the macro level of society (Bernardi et al., 2019; Mayer, 2009). Empirical life course studies have significantly enlarged our understanding of family behavior in Germany and across countries. Such studies have also contributed to social-stratification research by showing how family behavior differs across population subgroups and how it amplifies or ameliorates social and economic risks. However, the tendency of many empirical studies in this area to focus on single life course transitions has come at the expense of taking a more holistic view of family change, which was more prominent 20 years ago.

Beyond these shifts in theoretical and analytical perspectives, German family sociology has undergone a fundamental transformation in recent years. Researchers have increasingly expanded across the borders of German-speaking societies and have entered into international collaborations. The foundation of the Max Planck Institute for Demographic Research (MPIDR) in 1996 started a new wave of research at the interface of family demography and sociology. The MPIDR has advanced empirical research through a rigorous commitment to event-history modeling and has supported 
international data collection (e.g., the Generations and Gender Programme [GGP]) as well as international and interdisciplinary collaboration on family issues. The German Family Panel (pairfam), initiated in 2008, now provides more than ten years of panel data to examine family behavior. The National Educational Panel Study (NEPS), conducted by the Leibniz Institute for Educational Trajectories (LIfBi), has further strengthened research on the interplay of education and family life. FReDA is a recently launched large-scale panel survey devoted to family behavior in Germany and in cross-national comparison. It was initiated by the Federal Institute for Population Research, GESIS, and the pairfam consortium. All of these projects are strongly committed to the life course framework.

In addition, these trends towards the internationalization of German family sociology have led to shifts in publication strategies (see also Schneider and Aevermann, 2019). Twenty years ago, most research in family sociology was published in Germanlanguage journals, monographs, and edited books. Today, family sociologists increasingly publish in international journals, and even national family journals have taken an international turn. The Zeitschrift für Familienforschung has been renamed the Journal of Family Research, while the Zeitschrift für Bevölkerungswissenschaft has been renamed Comparative Population Studies. The articles published in both journals are now exclusively in English.

Given these developments, it has become more difficult to draw a line between "German family sociology" and international research on the family. The language in which an article is published is obviously no longer a useful criterion for such distinctions. In the absence of strict criteria, our article will primarily consider studies that have been conducted within a German institutional context or empirical studies that particularly deal with the German case. Within this frame, our aim is to provide an overview of what we consider to be the major achievements, landmark studies, and shortcomings of research that has dealt with family behavior and intimate relations over the last two decades. Since it is beyond the scope of this article to give a full bibliographical account of this large body of literature, we will refer to a selection of publications that represent various fields of research.

The remainder of this paper is organized as follows. Section 2 focuses on the particularities of family research that has dealt with differences in family behavior in East and West Germany as they relate to German reunification. We then summarize the large body of literature that has examined family behavior and employment in the context of changing gender roles (section 3). Section 4 addresses research on family forms and intergenerational relationships. Section 5 summarizes the potential of the rich dyadic and panel data that have become available in recent years. In this section, we also touch upon the innovations and limitations of official statistics. The concluding section 6 summarizes main achievements, dead ends, and gives an outlook on future family research. 


\section{The Unique Features of German Family Sociology after the Fall of the Wall}

Despite the move towards internationalization, certain developments in family sociology over the past two decades were unique to the German case or were not applicable to family research in other countries. German unification was a major historical turning point that also stimulated family research. The abrupt changes in family behavior after the fall of the Berlin Wall, including trends towards the postponement of parenthood and marriage in East Germany, were interpreted either as signs of the "Westernization" and "modernization" of family behavior or as responses to the adverse economic conditions and labor-market uncertainties that prevailed in East Germany during the 1990s. With the passage of time, it has become apparent that much of the early work on these developments relied on simplified assumptions. This particularly concerns the belief that the convergence of the economic conditions would inevitably force East German family behavior to "adapt" to the prevailing West German patterns. The East-West differences in family and marriage behavior that persist until today have required family researchers to think more carefully about what factors contribute to societal change, how values and behavior are transmitted across generations, and how responsive family behavior is to changing economic conditions and legal constraints. Moreover, in-depth research on differences in family attitudes and family behavior between East and West Germans revealed that West German family patterns were less "modern" than was previously assumed (Huinink et al., 2012). Some studies explicitly focused on East-to-West migrants, that is, men and women who were socialized in East Germany but were then exposed to the West German economic and normative context (Arránz Becker and Lois, 2010). An important lesson from these studies was that East German women who had moved to the West returned to work more rapidly after childbirth than West German women in comparable circumstances. It was also found that East-to-West migrants stuck to a pattern of early family formation that was typical of East Germans (Kreyenfeld and Vatterrott, 2018).

Comparative welfare-state research also provided a new impetus for research on family behavior. In his seminal book, Social Foundations of Postindustrial Economies, Esping-Andersen (1999) classified Germany as a conservative and familialistic welfare state. Feminist literature, such as Ostner's (1995) article Arm ohne Ehemann (Impoverished without a Husband) rigorously criticized the German system for its bias towards the male breadwinner model. Furthermore, international scholars unanimously agreed that family policies in Germany were locked in a conservative trajectory that contributed to both low fertility and low female employment rates.

Despite these criticisms, major family-policy reforms were not enacted until 2005. The cornerstones of the new era of German family policy have been the expansion of daycare for children under age three, which started in 2005, and the parental leave benefit reform (Elterngeld), which was enacted in 2007. While it was the then Federal 
Family Minister Ursula von der Leyen who eventually pushed these reforms through the legislative process, family sociologists like Hans Bertram, the lead author of the 2006 family report, laid out the path for change by showing how Germany's family policies and family patterns compared with those of other countries and with the Swedish model in particular (BMFSFJ, 2006).

\section{Family Behavior, Employment Patterns, and Changing Gender Roles}

Research on female employment and women's return to work, which dominated the family sociology literature of the 1980s and 1990s, has moved in a new direction over the last two decades. In addition to examining the effects of interruptions to mothers' careers, studies on parental employment explored a number of other questions, including the extent to which fathers have been taking leave to care for their children and how couples have been sharing parental responsibilities. There is a massive body of comparative research examining the interplay between family life, paid and unpaid work, gender, and social policies. These studies have highlighted the effects of institutional factors and labor-market conditions on female employment and have looked at how gender cultures influence couples' work-family arrangements (Steiber and Haas, 2010).

These cross-national studies have also demonstrated that, compared to their counterparts in other countries, couples in Germany are subject to the largest gender differences in working hours and in the division of labor in the home (Treas and Drobnič, 2010). These patterns have been attributed to the system of joint taxation of married couples, the large gender pay gap, and the ongoing lack of sufficient childcare (Hipp and Leuze, 2015). The family-policy reforms of the 2000s have led to slight increases in the full-time employment rates of mothers and the usage of parental leave by fathers. However, a large pay gap between men and women and a gendered division of paid and unpaid work between parents remain (OECD, 2017).

Researchers have increasingly adopted concepts such as "linked lives," "coupled careers," "dual-earner couples," and "dual-career couples" to highlight that employment decisions are made in a couple context. In these studies, the couple context is defined as the locus where interrelated and gendered life courses are shaped and social inequality, particularly with respect to gender, is therefore (re-)produced (Rusconi et al., 2013). The assumption that ties between family members can represent both sources of support and constraints has, for example, been investigated with respect to residential relocations (Auspurg and Abraham, 2007) and promotion to leadership positions (Bröckel et al., 2015). By applying a relational perspective to couples' resources, these studies have provided important insights into bargaining processes and their gender-specific consequences, often with an explicit focus on better-educated couples (Rusconi and Solga, 2011). Using different theoretical and 
methodological approaches, Wimbauer (2012) undertook an in-depth examination of the trade-offs within dual-career couples "between recognition and inequality." Another line of research has looked into the correlates and consequences of a woman becoming the main earner in the family (Klenner et al., 2012). Building on earlier work by Koppetsch and Burkart on milieu-specific latent gender norms, Koppetsch and Speck (2015) reconstructed the milieu-specific coping strategies and shifts in gender identities among couples in which the male partner became unemployed. Overall, less research has been conducted on the dynamics of employment patterns and the negotiation processes among dual-earner couples with lower educational levels.

Numerous studies on the gendered division of paid work, domestic work, and childcare have highlighted the overlapping of these different life domains and have looked at how households and families coordinate and negotiate the allocation of time and resources to these tasks (Schulz, 2010). The findings of such studies consistently show that the gendered division of unpaid work is more unequal than the gendered division of paid work. Thus, even though there have been substantial changes in women's employment patterns and in women's and men's attitudes toward gender roles, routine housework, and childcare are still largely seen as "women's work." None of the conventional theoretical approaches-the time-availability perspective, the relative-resources approach, the economic-dependency model, or the gender-role perspective-fully account for the slow pace of change in the domestic sphere.

Longitudinal studies have furthermore emphasized that couples tend to move towards a more unequal division of labor over the course of their relationship. Getting married and having a first child are important turning points in the shift towards a more unequal division of labor (Dechant et al., 2014). This research has benefitted from the integration of social-psychological approaches (e.g., equity theory) that can help shed light on how normative and structural factors complement each other in the partners' evaluations of how they divide up paid employment and domestic work. A prime example of an investigation of the dynamic interrelation between gendered attitudes, identities, and institutions is a comparative qualitative study by Grunow and Evertsson (2016), which related couples' parenting ideals and plans to family policies and gender culture. However, a systematic examination of the development of each partner's gender-role attitudes and actual behavior over the course of a relationship is still missing. More generally, there is a lack of strategic research that goes beyond investigating heterosexual couples in order to gain a broader understanding of the division of labor in the context of family-related transitions. Paying more attention to gender expression and identity might help researchers better understand the mechanisms that underlie the gendered division of labor. In this regard, a qualitative study on couple dynamics during pregnancy by Hirschauer (2019) has revealed that the age difference within couples contributes to the remarkable persistence of parenting as dominantly feminine.

While quantitative methods have dominated recent research on couple behavior, qualitative research has provided a more nuanced picture of how family and house- 
hold behavior and fertility decisions are negotiated and of how couples define and justify a gender-specific division of labor (Huinink and Röhler, 2005; Koppetsch and Speck, 2015; Kühn, 2004). Furthermore, the use of mixed methods in family sociology is starting to bridge qualitative and quantitative research (Helfferich, 2001; Schneider et al., 2002), even though such approaches are still rare. Whether the mixed-methods approach (Knappertsbusch/Langfeldt/Kelle, MIXED-METHODS AND MULTI METHOD RESEARCH, this volume) eventually results in a reintegration of methodologies or simply leads to the emergence of another form of methodological specialization remains to be seen.

\section{Family Forms, Partnerships, and Intergenerational Relationships}

As we mentioned above, investigations of the "pluralization" of family forms and living arrangements in Germany conducted in the 1990s were heavily influenced by individualization theory. While the impact of concepts like individualization on empirical research surely diminished in the new millennium, several studies have still addressed the pluralization of family forms (Brüderl, 2004; Wagner and Cifuentes, 2014). Moreover, there is a large body of-predominantly descriptive-literature that uses different classification approaches to depict the prevalence of "modern," "alternative," or "non-traditional” family forms. Recent studies have also implemented a dynamic perspective on family forms by employing sequence analysis to map living arrangements across the life course (Fasang, 2014; Feldhaus and Huinink, 2011; Zimmermann, 2020). In general, this research has shown that, over the last few decades, the prevalence of the "traditional family" (parents living together with their biological children) has declined, while cohabiting couples, same-sex unions, singleparent families, as well as stepfamilies have increased. Moreover, qualitative studies have provided a more detailed rendering of the meaning of single parenthood (Schneider et al., 2001). More recent analyses on lone parenthood have sharpened our understanding of its variations along regional, cultural, generational, and institutional lines as well as its increasing heterogeneity regarding social origin, resources, and re-partnering behavior (Bastin, 2019; Bernardi and Mortelmans, 2018). Researchers have also explored the complexities and the behavior of stepfamilies in Germany as well as from a cross-national perspective (Martin and Le Bourdais, 2008; Steinbach, 2010; Thomson, 2004).

More broadly, family sociologists are increasingly turning their attention to the question of how partnerships and intimate relationships evolve. A strand of research has scrutinized the institutionalization of partnerships by reconstructing each step from the first kiss, to cohabitation, to marriage (Kopp et al., 2010; Lenz, 2003). Other studies have analyzed the dynamics of separations and divorces, taking into account individual and structural predictors and applying both sociological and psychological 
perspectives (Arránz Becker, 2008; Burkart, 2018; Hill, 2004; Lenz, 2003; Weiß and Wagner, 2010). This research has been accompanied by a growing interest in the study of social relations and social networks (Diewald et al., 2009; Hollstein, 2001; Lenz and Nestmann, 2009; Häußling, SOCIAL NETWORKS, this volume). Moreover, a significant body of research has examined the macro-structural conditions that influence partnership behavior. These studies have shown that partner-market indicators (measured by the regional sex ratios, the age structure, etc.) not only determine the search costs and the degree to which an intimate relationship represents a "match" but also predict partnership satisfaction and stability (Häring et al., 2014).

Research on intergenerational relationships based on large datasets (such as the Survey of Health, Ageing and Retirement in Europe [SHARE] or the German Ageing Survey) has considerably enhanced our understanding of the consequences of population aging on family relations. A theoretical approach that is often used in such research is the concept of intergenerational solidarity (Bengtson, 2001). Most studies have found that there is an extensive exchange between parents and their adult children, with most material transfers (often financial support) flowing from parents to (adult) children, and most immaterial services flowing in the other direction. These studies have examined various dimensions of intergenerational solidarity, such as emotional, immaterial, and material exchange processes; the transmission of norms and values; contact frequency; and both parent-child and grandparent-grandchild relationships (Arránz Becker et al., 2013; Hank et al., 2017; Kopp and Steinbach, 2009; Szydlik, 2016). Finally, family research has investigated the living and family-care arrangements of elderly people, as well as their health, social contacts, and networks (Mahne et al., 2017). A more detailed account of intergenerational family help and care in demographically aging societies is given by Höpflinger, DEMOGRAPHY AND AGING, this volume.

Recent research has also deepened our understanding of parent-child relationships and child development. By borrowing heavily from the psychology and the pedagogy literature, "new childhood studies" have shifted the attention to the child's agency, activities, and perceptions of the parental behavior. Researchers have investigated how child development is related to the socio-economic status of the parents, poverty risks, parenting behavior, and other familial socialization conditions (Bertram, 2017; Esser et al., 2016; Kaiser et al., 2019). Scholars have explored the consequences of co-parenting and parental conflicts on partnership quality and child development. In addition, the family-school context, the role of parental educational aspirations, the parent-child relationship, and parental involvement in matters of schooling have emerged as research topics in family sociology (Walper et al., 2015). Another strand of research has looked at how sibling relationships and sibling status affect child development as well as children's educational outcomes. It has, for example, been shown that sibling status has an impact on the prevalence of harmonious, hostile, affective, or uninvolved sibling relationships (Grätz, 2018; Hank and Steinbach, 2018; Kersting and Feldhaus, 2016; Walper et al., 2009). 
In response to the high divorce rates, many family sociologists and psychologists have turned their attention to the effects of separation and divorce on family behavior as well as on the children's and the parents' wellbeing (Zartler et al., 2015). Among the issues investigated are shared custody (Langmeyer, 2015), contact with the parent not living in the household (Köppen et al., 2018), and the impact of separation on the wellbeing of children and adolescents. Furthermore, research has been done on the quality of relationships within stepfamilies (Kunze, 2015) and the frequency, type, and quality of contact between parents and adult (step)children (Arránz Becker et al., 2015).

\section{Innovations in Official Statistics and the Potential of Dyadic and Panel Data}

The developments in family sociology over the last 20 years must also be understood in conjunction with the data that have become available. An important "official" data source for analyzing family and household structures is the micro census conducted by Germany's Federal Statistical Office (Statistisches Bundesamt). It is important to note that since 2005 the Federal Statistical Office has been using a new "official definition" of a family unit based on the presence of children in the household. Thus, cohabiting couples with children and single adults with children are now considered a family unit, whereas a married couple without children is not. The Federal Statistical Office changed the definition in response to the long-standing call from family sociologists for the growing prevalence of cohabiting unions with children to be properly accounted for in the collection of the data. Other "non-traditional" family forms, such as stepfamilies and non-resident parents, cannot be identified in the data, though.

Important changes also concern the fertility indicators provided by the Federal Statistical Office. No official indicators on childlessness and age at first childbirth were available until recently. It is only since 2009 that the system of vital statistics started to register the biological order of birth (instead of the order of birth in a marital union). Furthermore, the micro census conducted in 2008 was the first to include a question on the number of children ever born to a female respondent. However, as this question was posed only to females, "male childlessness" still cannot be studied. Despite this limitation, the collection of data on the number of children of women enabled researchers to generate robust indicators of childlessness (Kreyenfeld and Konietzka, 2017) and total fertility by socio-demographic indicators, including migration background, a characteristic that has also been more thoroughly surveyed since 2005 (Bujard, 2015). The inclusion of country of origin and further migrationspecific variables has enlarged the potential of the micro census to examine family behavior and living arrangements for migrant populations.

Beyond the official statistics, social-science datasets-such as the Family und Fertility Survey (FFS), the German Socio-Economic Panel (SOEP), the Family Surveys 
of the German Youth Institute, and the Life Course Studies of the Max Planck Institute for Human Development-have been valuable sources for longitudinal data analysis. However, the German Family Panel (pairfam), which was initiated in 2008, has been particularly helpful in broadening the potential for family research. It collects data on fertility desires, fertility intentions, and family attitudes. The panel design thus enables researchers to study questions such as whether positive fertility intentions have been stable across time and whether these intentions eventually lead to fertility transitions. Moreover, numerous studies have looked at how migration background, occupation, socio-economic conditions, religious affiliation, economic uncertainties, temporary working contracts, value orientations, and personality factors are related to fertility, family behavior, and family-related attitudes (Gebel and Giesecke, 2009; Kuhnt, 2014; Lois, 2011; Maul, 2012; Milewski, 2007, 2010; Reis et al., 2011; Schmitt, 2012; Schneider et al., 2015; Schnor, 2014). Apart from the anchor respondent, the German Family Panel surveys the respondent's children, current partner (including non-residential partners), and parents. Network analysis has been employed to show how friendship networks, parental expectations, social pressure, social support, and "social contagion" influence fertility behavior (Lois, 2016). This type of research has also provided us with a more nuanced picture of how couples make decisions (Stein et al., 2014). There is, for example, evidence that the transition to the first child is a joint decision, whereas the female partner plays the dominant role in the decision to have another child (Bauer and Kneip, 2012). The dyadic perspective has also emphasized the different views that couples tend to have on everyday activities, such as on the division of housework.

Methodologically, researchers have increasingly capitalized on the large pool of panel data to employ sophisticated modeling strategies, in particular event-history analysis, panel regression models, multilevel analysis, or dynamic panel approaches (Brüderl et al., 2019; Mund and Nestler, 2019; Barth/Blasius, QUANTITATIVE METHODS, this volume). Fixed-effects regression started seeping into family research around the turn of the century, providing new techniques for identifying the causal influences of partnership and family behavior. Although advanced event-history modeling, such as multi-process modeling, has been employed by family researchers, interest in this technique seems to have faded in recent years, possibly because of the strong assumptions these models rely on. There is a growing body of literature that is based on sequence analysis (Aisenbrey and Fasang, 2017; Zimmermann and Konietzka, 2018). In addition to providing more comprehensive insights into family life course dynamics, this research has responded to the call for more vivid graphical visualizations of research results. 


\section{Achievements, Dead Ends, and Outlook for Future Research}

In his review published in the Soziologische Revue 20 years ago, Richter (2000: 68-70) identified seven research streams that he believed family sociology would further develop in the near future. Five of these streams have shaped family sociology in Germany over the last 20 years: (1) the sociology of the life course and of living arrangements; (2) the sociology of intergenerational relationships; (3) research on couple relationships and partnership quality; (4) the growth in the interdisciplinary character of family research; and (5) intercultural studies on the meaning of family and partnership, particularly with respect to migrant families. While he was correct with regard to these five important points, his other two predictions were not fully realized.

First, Richter anticipated that family indicators would feature more prominently in national and international reporting systems. It is indeed the case that the German Data Report (Datenreport) devotes more space to family-related topics now than in the past. There are, moreover, several international indicator systems that cover familyrelated topics, such as the OECD family database and the contextual database of the Generations and Gender Programme. These indicators have proven useful in examining differences in family policies and behavior between countries. However, the expectations of the early years that the collection of contextual information would boost multilevel research and enrich our understanding of the effects of contextual factors on individual decision-making have yet to be fulfilled.

Second, Richter predicted a further development and diversification of theoretical approaches. While he was right that the rational-choice approach would be refined in the following years, the theoretical approaches that are currently being used barely go beyond the bifurcation between rational choice and related micro-level accounts on the one hand and constructivist approaches on the other.

How can we finally evaluate the achievements and shortcomings of German family sociology over the past two decades? It seems safe to acknowledge that research on intimate relationships and the family has undergone a major transition. Research activities have clearly taken the path of internationalization and have become more interdisciplinary. The controversies that dominated family sociology in the 1980s and 1990s-such as discussions about the decay of the family and theoretical debates about pluralization-have largely given way to empirical research based on rigorous methods and complex datasets. As a result, family sociology in Germany has developed into a highly differentiated research landscape that addresses a wide range of topics and questions. It is nowadays common for mainstream family researchers to employ a longitudinal research design, large-scale datasets, and a cross-national perspective. These developments started well before the turn of the century; however, the strong commitment of researchers to (rational) action theory and the life course paradigm is a more recent development. Another major aspect of change is that family 
sociology has opened up. In many cases, scholars who classify themselves as family sociologists contribute to adjacent fields and areas of research, such as social-stratification research, social-network analysis, demography, and social policy. In the same vein, research on the labor market, migration, and social inequality has increasingly taken into account individuals' commitment in intimate relationships and families. These developments clearly represent major achievements, not least because they have fostered integrative research perspectives that link family dynamics to other life domains. However, a strong reliance of German family sociology on "normal science" has come at a cost. This has been illustrated above by the lack of theoretical diversity that we identified among mainstream family sociologists. Scholars who adopt a more universal view or who contribute to the advancement of theory have become a rare species over the last 20 years. In line with these developments, universalists and scholars of "the family" are barely visible in today's public debates in Germany.

What direction will family sociology take in the next two decades? It is likely that the prominent themes will include couple relations, gender-role behavior, workfamily conflicts, the impact of social and family policies on family behavior, the relationships of family members within and beyond the household context, and living arrangements of the elderly and intergenerational relationships in aging societies. Family sociology will also continue to contribute to the understanding of social and economic disparities, including wealth inequalities that exist by gender, family type, migration background, and region.

Beyond these topics, there are at least three areas of research that have received little attention in the past but might provide new perspectives for family sociologists in the years to come.

First, family sociologists have tended to view with a certain degree of suspicion the claim that biological factors are determinants of human behavior. For this reason, research in this area has been rather scattered (Huinink et al., 2015; Kolk and Schnettler, 2013). However, this attitude seems to be changing. An indication that a shift is occurring is that survey data on biomarkers are increasingly being collected. The TWIN-LIFE project is an example of a landmark study that examines how genetic factors influence family behavior and social inequality (e.g., Gottschling et al., 2019). In addition, the increasing use of assisted reproduction has led researchers to pay more attention to the biological foundations of having children (Trappe, 2017). It is also likely that the question of how the mental and the physical health of children and their parents affect family life and family behavior will occupy the next generation of family sociologists.

Second, it appears that the discourse on digitalization has yet to have any largescale effects on German family sociology. As early as in the 2000s, Hans-Peter Blossfeld led a large-scale project on the role of dating platforms in partnership behavior (Skopek et al., 2011). However, to our knowledge, no major initiatives followed. Digital "big data" are currently being exploited for demographic analysis. The ability to web-scrape internet and social media content has led to the emergence of new types 
of data sources for political scientists. Family sociologists have not yet tapped into this option on any substantial scale. However, it seems safe to assume that a growing number of younger family scholars will eventually take advantage of the new data sources that are available to study family behavior. Furthermore, there is a growing awareness of the role that social media, and digitalization more broadly, may have on family life, family relations, and family behavior. How digitalization shapes labor markets, work patterns, family relations, family care, and the compatibility of work and family life will certainly become a relevant social-policy topic.

Finally, gender equality is a topic high on the agenda of both the European Union and the German government. Up to now, this policy goal has mainly been addressed through the expansion of public daycare and the inclusion of women in the labor market. Efforts to reform working-time regulations, reduce the working hours of fathers, and promote changes in the behavior and the organizational cultures of employers were never embraced with the same enthusiasm. While family sociologists have advocated the dual-earner model, they have lacked a clear vision or policy strategy for achieving gender equality beyond calling for an expansion of public daycare. We do not yet know how the transformation of the labor market through information technologies will shape family life and behavior in the years to come-that is, whether it will generate new freedoms for parents to organize their family life as they wish or whether it will lead to the emergence of new social risks and divisions. The ability of future research to address these questions depends heavily on the continuity and innovations in data collection that sufficiently reflect the changes in the labor market.

\section{References}

Aisenbrey, S.; Fasang, A. The Interplay of Work and Family Trajectories over the Life Course: Germany and the United States in Comparison. American Journal of Sociology 2017, 122, 1448-1484.

Ajzen, I. From Intentions to Action: A Theory of Planned Behavior. In Action-Control: From Cognition to Behavior; Kuhl, J.; Beckmann, J., Eds.; New York: Plenum, 1985; pp 11-38.

Arránz Becker, O. Was hält Partnerschaften zusammen?; Wiesbaden: VS, 2008.

Arránz Becker, O.; Lois, D. Westdeutsche, ostdeutsche und mobile Frauen: Was erklärt die Unterschiede in ihrem Heiratsverhalten. Soziale Welt 2010, 61, 5-62.

Arránz Becker, O.; Lois, N.; Salzburger, V. Intergenerational Contact Between Parents and Adult (Step)Children: The Role of Biological Descent and Co-Residence Patterns. In Family Dynamics after Separation; U. Zartler; V. Heintz-Martin; Arránz Becker, O., Eds.; Barbara Budrich: Opladen, 2015; pp 43-63.

Arránz Becker, O.; Salzburger, V.; Lois, N.; Nauck, B. What Narrows the Stepgap? Closeness Between Parents and Adult (Step)Children in Germany. Journal of Marriage and Family 2013, 75, 1130-1148.

Auspurg, K.; Abraham, M. Die Umzugsentscheidung von Paaren als Verhandlungsproblem. Kölner Zeitschrift für Soziologie und Sozialpsychologie 2007, 59, 271-293. 
Bastin, S. Single Mothers' New Partners. Partnership and Household Formation in Germany, Journal of Marriage and Family 2019, 81, 991-1003.

Bauer, G.; Kneip, T. Fertility From a Couple Perspective: A Test of Competing Decision Rules on Proceptive Behaviour. European Sociological Review 2012, 29, 535-548.

Bengtson, V. L. Beyond the Nuclear Family: The Increasing Importance of Multigenerational Bonds (The Burgess Award Lecture). Journal of Marriage and Family 2001, 63, 1-16.

Bernardi, L.; Mortelmans, D., Eds. Lone Parenthood in the Life Course; Springer: Cham, 2018.

Bernardi, L.; Huinink, J.; Settersten, R. A. The Life Course Cube: A Tool for Studying Lives. Advances in Life Course Research 2019, 41, Article 100258.

Bertram, H. Zukunft mit Kindern, Zukunft für Kinder. Der UNICEF-Bericht zur Lage der Kinder in Deutschland im europäischen Kontext; Barbara Budrich: Opladen, 2017.

BMFSFJ 7. Familienbericht. Familie zwischen Flexibilität und Verlässlichkeit. BMSFJ: Berlin, 2006.

Bröckel, M.; Busch-Heizmann, A.; Golsch, K. Headwind or Tailwind: Do Partners' Resources Support or Restrict Promotion to a Leadership Position in Germany? European Sociological Review 2015, 31, 533-545.

Brüderl, J. Die Pluralisierung partnerschaftlicher Lebensformen in Westdeutschland und Europa. Aus Politik und Zeitgeschichte 2004, B 19, 3-10.

Brüderl, J.; Kratz, F.; Bauer, G. Life Course Research with Panel Data: An Analysis of the Reproduction of Social Inequality. Advances in Life Course Research 2019, 41, Article 100247.

Bujard, M. Kinderlosigkeit in Deutschland: Wie interagieren Bildung, Wohnort, Migrationshintergrund, Erwerbstätigkeit und Kohorte? Zeitschrift für Familienforschung 2015, 3, 255-269.

Burkart, G. Soziologie der Paarbeziehung; Springer VS: Wiesbaden, 2018.

Dechant, A.; Rost, H.; Schulz, F. Die Veränderung der Hausarbeitsteilung in Paarbeziehungen. Ein Überblick über die Längsschnittforschung und neue empirische Befunde auf Basis der pairfam-Daten. Zeitschrift für Familienforschung 2014, 26, 144-168.

Diewald, M.; Sattler, S.; Wendt, V.; Lang, F. R. Verwandtschaft und verwandtschaftliche Beziehungen. In Handbuch persönliche Beziehungen; Lenz, K.; Nestmann, F., Eds.; Juventa: Weinheim, 2009; pp 423-445.

Esping-Andersen, G. Social Foundations of Postindustrial Economies; Oxford University Press: Oxford, 1999.

Esser, F.; Baader, M.; Betz, T.; Hungerland, B. Reconceptualising Agency and Childhood; Routledge: London/New York, 2016.

Fasang, A. New Perspectives on Family Formation: What Can We Learn from Sequence Analysis? In Advances in Sequence Analysis: Methods, Theories and Applications; Blanchard, P.; Bühlmann, F.; Gauthier, J., Eds.; Springer: Cham, 2014.

Feldhaus, M.; Huinink, J. Multiple Elternschaft. Eine Analyse zur Vielfalt von Elternschaft und Folgepartnerschaften. Zeitschrift für Familienforschung 2011, Sonderheft 8, 77-105.

Gebel, M.; Giesecke, J. Ökonomische Unsicherheit und Fertilität. Die Wirkung von Beschäftigungsunsicherheit und Arbeitslosigkeit auf die Familiengründung in Ost- und Westdeutschland. Zeitschrift für Soziologie 2009, 38, 399-417.

Gottschling, J.; Hahn, E.; Beam, C. R.; Spinath, F. M.; Carroll, S.; Turkheimer, E. Socioeconomic Status Amplifies Genetic Effects in Middle Childhood in a Large German Twin Sample. Intelligence 2019, 72, 20-27.

Grätz, M. Competition in the Family: Inequality between Siblings and the Intergenerational Transmission of Educational Advantage. Sociological Science 2018, 5, 246-269.

Grunow, D.; Evertsson, M., Eds. Couples' Transitions to Parenthood: Analysing Gender and Work in Europe; Edward Elgar: Cheltenham, 2016.

Häring, A.; Klein, T.; Stauder, J.; Stoye, K. Der Partnermarkt und die Gelegenheiten des Kennenlernens; Springer VS: Wiesbaden, 2014. 
Hank, K.; Steinbach, A. Intergenerational Solidarity and Intergenerational Relations between Adult Siblings. Social Science Research 2018, 76, 55-64.

Hank, K.; Salzburger, V.; Silverstein, M. Intergenerational Transmission of Parent-Child Relationship Quality: Evidence from a Multi-Actor Survey. Social Science Research 2017, 67, 129-137.

Helfferich, C. Frauen leben. Eine Studie zu Lebensläufen und Familienplanung; BZgA: Cologne, 2001.

Hill, P. B. Interaktion und Kommunikation; Ergon: Würzburg, 2004.

Hipp, L.; Leuze, K. Institutionelle Determinanten einer partnerschaftlichen Aufteilung von Erwerbsarbeit in Europa und den USA. Kölner Zeitschrift für Soziologie und Sozialpsychologie 2015, 67, 659-684.

Hirschauer, S. Mein Bauch gehört uns. Gynisierung und Symmetrisierung der Elternschaft bei schwangeren Paaren. Zeitschrift für Soziologie 2019, 48, 6-22.

Hollstein, B. Grenzen sozialer Integration. Zur Konzeption informeller Beziehungen und Netzwerke; VS: Wiesbaden, 2001.

Huinink, J.; Röhler, A. Liebe und Arbeit in Paarbeziehungen; Ergon: Würzburg, 2005.

Huinink, J.; Kreyenfeld, M.; Trappe, H., Eds. Familie und Partnerschaft in Ost- und Westdeutschland. Ähnlich und doch immer noch anders; Babara Budrich: Opladen, 2012.

Huinink, J.; Kohli, M.; Ehrhardt, J. Explaining Fertility. The Potential for Integrative Approaches: Introduction to the Special Collection "Theoretical Foundations of the Analysis of Fertility". Demographic Research 2015, 33, 93-112.

Kaiser, T.; Li, J. Pollmann-Schult, M. Evening and Night Work Schedules and Children's Social and Emotional Well-Being. Community, Work \& Family 2019, 22, 167-182.

Kersting, L.; Feldhaus, M. Die Qualität von Geschwisterbeziehungen im jungen und mittleren Erwachsenenalter in Abhängigkeit des Verwandtschaftsstatus. Zeitschrift für Soziologie der Erziehung und Sozialisation 2016, 36, 382-401.

Klenner, C.; Menke, K.; Pfahl, S. Flexible Familienernährerinnen: Moderne Geschlechterarrangements oder prekäre Konstellationen?; Barbara Budrich: Opladen/Berlin/Toronto, 2012.

Köppen, K.; Kreyenfeld, M.; Trappe, H. Loose Ties? Determinants of Father-Child Contact after Separation in Germany. Journal of Marriage and Family 2018, 80, 543-548.

Kolk, M.; Schnettler, S. Parental Status and Gender Preferences for Children: Is Differential Fertility Stopping Consistent with the Trivers-Willard Hypothesis? Journal of Biosocial Science 2013, 45, 683-704.

Kopp, J.; Steinbach, A. Generationenbeziehungen. Ein Test der intergenerational-stake-Hypothese. Kölner Zeitschrift für Soziologie und Sozialpsychologie 2009, 61, 283-294.

Kopp, J.; Lois, D.; Kunz, C.; Arránz Becker, O. Verliebt, verlobt, verheiratet. Institutionalisierungsprozesse in Partnerschaften; VS: Wiesbaden, 2010.

Koppetsch, C.; Speck, S. Wenn der Mann kein Ernährer mehr ist - Geschlechterkonflikte in Krisenzeiten; Suhrkamp: Berlin, 2015.

Kreyenfeld, M.; Konietzka, D., Eds. Childlessness in Europe: Contexts, Causes, and Consequences; Springer: Dodrecht, 2017.

Kreyenfeld, M.; Vatterrott, A. Salmon Migration and Fertility in East Germany. An Analysis of Birth Dynamics around German Reunification. Zeitschrift für Familienforschung 2018, 30, 247-268.

Kühn, T. Berufsbiografie und Familiengründung; VS: Wiesbaden, 2004.

Kuhnt, A.-K. Kinderwünsche im Lebensverlauf. Analysen auf Basis des Beziehungs- und Familienpanels (pairfam); Dissertation. Universität Rostock, 2014.

Kunze, S. Die Beziehungsqualität in Stiefvater- und Stiefmutterfamilien Gemeinsamkeiten und Unterschiede der Ressourcennutzung. Working Paper 03/2015. Katholische Universität Eichstätt-Ingolstadt, 2015. 
Langmeyer, A. Sorgerecht, Coparenting und Kindeswohl. Eltern Sein in nichtehelichen Lebensgemeinschaften; Springer VS: Wiesbaden, 2015.

Lenz, K. Soziologie der Zweierbeziehung; VS: Wiesbaden, 2003.

Lenz, K.; Nestmann, F. Handbuch persönliche Beziehungen. Juventa: Weinheim, 2009.

Lois, D. Church Membership and Church Attendance Across Time. A Trend Analysis Considering Differences between East and West Germany. Comparative Population Studies 2011, 36, 127-160.

Lois, D. Types of Social Networks and the Transition to Parenthood. Demographic Research 2016, 34, 657-688.

Mahne, K.; Wolff, J. K.; Simonson, J.; Tesch-Römer, C. Altern im Wandel. Zwei Jahrzehnte Deutscher Alterssurvey; Springer VS: Wiesbaden, 2017.

Martin, V.; Le Bourdais, C. Stepfamilies in Canada and Germany. A Comparison. In Familiale Beziehungen, Familienalltag und soziale Netzwerke; Bien W.; Marbach, J. H., Eds.; VS: Wiesbaden, 2008, pp 241-278.

Maul, K. Der Einfluss der beruflichen Tätigkeit auf die Familiengründung; Ergon: Würzburg, 2012.

Mayer, K. U. New Directions in Life Course Research. Annual Review of Sociology 2009, 35, 413-433.

Milewski, N. First Child of Immigrant Workers and their Descendants in West Germany: Interrelation of Events, Disruption, or Adaptation? Demographic Research 2007, 17, 859-896.

Milewski, N. Fertility of Immigrants: A Two-Generational Approach in Germany; Springer: Berlin/Heidelberg, 2010.

Mund, M.; Nestler, S. Beyond the Cross-Lagged Panel Model: Next-Generation Statistical Tools for Analyzing Interdependencies Across the Life Course. Advances in Life Course Research 2019, 41, Article 100249.

Nauck, B. Value of Children and the Framing of Fertility: Results from a Cross-Cultural Comparative Survey in 10 Societies. European Sociological Review 2007, 23, 615-629.

OECD. Dare to Share - Deutschlands Weg zur Partnerschaftlichkeit in Familie und Beruf, 2017. dx.doi.org/10.1787/9789264263420-de

Ostner, I. Arm ohne Ehemann? Sozialpolitische Regulierung von Lebenschancen für Frauen im internationalen Vergleich. Aus Politik und Zeitgeschichte 1995, B36-37, 3-12.

Reis, O.; Dörnte, M.; Lippe, H. v. d. Neuroticism, Social Support, and the Timing of First Parenthood: A Prospective Study. Personality and Individual Differences 2011, 50, 381-386.

Richter, R. Familiensoziologie: Forschungsthemen, Forschungsaufgaben. Soziologische Revue 2000, Sonderheft 5, 61-70.

Rusconi, A.; Solga, H, Eds. Gemeinsam Karriere machen: Die Verflechtung von Berufskarrieren und Familie in Akademikerpartnerschaften; Barbara Budrich: Opladen/ Farmington Hills, 2011.

Rusconi, A.; Wimbauer, C.; Motakef, M.; Kortendiek, B.; Berger, P. A., Eds. Paare und Ungleichheit(en): Eine Verhältnisbestimmung; Barbara Budrich: Opladen/Berlin/Toronto, 2013.

Schmitt, C. A Cross-National Perspective on Unemployment and First Births. European Journal of Population 2012, 28, 303-335.

Schneider, N. F.; Aevermann, T. Familienforschung im Wandel. Trends und Perspektiven. Beziehungsweise 2019, 6-10.

Schneider, N. F.; Krüger, D.; Lasch, V.; Limmer, R.; Matthias-Bleck, H. Alleinerziehen: Vielfalt und Dynamik einer Lebensform; Kohlhammer: Stuttgart/Berlin/Cologne, 2001.

Schneider, N. F.; Limmer, R.; Ruckdeschel, K. Mobil, flexibel, gebunden. Familie und Beruf in der mobilen Gesellschaft; Campus: Frankfurt a.M./New York, 2002.

Schneider, N. F.; Diabaté, S.; Ruckdeschel, K. Famlienleitbilder in Deutschland; Barbara Budrich: Opladen/Berlin/Toronto, 2015.

Schnor, C. The Contexts of Partnerships and Childbearing as Determinants of Union Stability. Dissertation. Universität Rostock, 2014. 
Schulz, F. Verbundene Lebensläufe: Partnerwahl und Arbeitsteilung zwischen neuen Ressourcenverhältnissen und traditionellen Geschlechterrollen; VS: Wiesbaden, 2010.

Skopek, J.; Schulz F.; Blossfeld, H.-P. Who Contacts Whom? Educational Homophily in Online Mate Selection. European Sociological Review 2011, 27, 180-195.

Steiber, N.; Haas, B. Begrenzte Wahl - Gelegenheitsstrukturen und Erwerbsmuster in Paarhaushalten im europäischen Vergleich. Kölner Zeitschrift für Soziologie und Sozialpsychologie 2010, 62, 247-276.

Stein, P.; Willen, S.; Pavetic, M. Couples' Fertility Decision-Making. Demographic Research 2014, 30, 1697-1732.

Steinbach, A. Generationenbeziehungen in Stieffamilien. VS: Wiesbaden, 2010.

Szydlik, M. Sharing Lives. Adult Children and Parents; Routledge: London, 2016.

Thomson, E. Step-Families and Childbearing Desires in Europe. Demographic Research 2004, Special Collection 3, 117-134.

Trappe, H. Assisted Reproductive Technologies in Germany: A Review of the Current Situation. In Childlessness in Europe: Contexts, Causes, and Consequences; M. Kreyenfeld; Konietzka, D., Eds; Springer: Dodrecht, 2017; pp 269-288.

Treas, J.; Drobnič, S., Eds. Dividing the Domestic: Men, Women, and Houshold Work in Cross-National Perspective; Stanford University Press: Stanford, CA, 2010.

Wagner, M.; Cifuentes, I. V. Die Pluralisierung der Lebensformen - ein fortlaufender Trend? Comparative Population Studies 2014, 39, 73-97.

Walper, S.; Thönnissen, C.; Alt, P. Einflüsse von akademischer Sozialisation und der Verbundenheit mit den Eltern auf die schulischen Leistungen von Kindern und Jugendlichen. Zeitschrift für Familienforschung 2015, 27, 152-172.

Walper, S.; Thönnissen, C.; Wendt, E.-V.; Bergau, B. Geschwisterbeziehungen in riskanten Familienkonstellationen. Sozialpädagogisches Institut des SOS-Kinderdorf e.V.: Munich, 2009.

Weiß, B.; Wagner, M. Beeinflussen Konflikte die Partnerschaftsstabilität? Eine Längsschnittanalyse auf der Grundlage zweier Paarbefragungen. In Partnerschaften und die Beziehungen zu Eltern und Kindern. Befunde zur Beziehungs- und Familienentwicklung in Deutschland; Walper, S.; Wendt, E.-V., Eds.; Ergon: Würzburg, 2010; pp 135-152.

Wimbauer, C. Wenn Arbeit Liebe ersetzt: Doppelkarriere-Paare zwischen Anerkennung und Ungleichheit; Campus: Frankfurt a.M./New York, 2012.

Zartler, U.; Heintz-Martin, V.; Arránz Becker, O. Family Dynamics after Separation; Barbara Budrich: Opladen, 2015.

Zimmermann, O. Destandardization in Later Age Spans in Western Germany. Evidence from Sequence Analysis of Family Life Courses. Advances in Life Course Research 2020, Article 100287.

Zimmermann, 0.; Konietzka, D. Social Disparities in Destandardization. Changing Family Life Course Patterns in Seven European Countries. European Sociological Review 2018, 34, 64-78. 
